\title{
How Sustainable Is The Use of Natural Resources in Brazil?
}

\author{
Fernando Antonio dos Santos Fernandez*, Pâmela Castro Antunes, \\ Leandro Macedo \& Carlos André Zucco
}

Departamento de Ecologia, Universidade Federal do Rio de Janeiro - UFRJ, Rio de Janeiro, RJ, Brazil

\begin{abstract}
The concept of sustainability is that present use of a resource would not prevent it being available for future generations. For exploited biological populations, sustainability is a demographic question. Herein we reviewed studies (released 1987-2010) evaluating presumably sustainable use of timber, hunting and non-timber forest products (NTFP) in Brazil. The studies analysed 239 cases (each case being one species evaluated in one study). Sustainability could be evaluated only in 126 cases studied with a demographic approach, $48 \%$ of which (61/126) showed unsustainable exploitations. The situation was worst for timber (24/39), intermediate for hunting (35/78) and best for NTFP (2/9). Cascading effects on other species were detected in 11/66 cases. Our results show that many presumed sustainable natural resource exploitations in Brazil are actually not sustainable. Clearly, sustainability needs more testing; the concept must be used more carefully.
\end{abstract}

Key words: Sustainability, Sustainable Use, Timber, Hunting, Non-Timber Forest Products.

\section{Introduction}

Sustainability has become an extremely popular concept since "sustainable development" was defined by the Brundtand Report (World Comission on Environment and Development 1987) as "development that meets the needs of the present without compromising the ability of future generations to meet their own needs" The concept has been used in many contexts, including exploitation of natural resources (Inyang et al. 2009).

Nowadays, combined effects of population and economic growth have spread exploitation of natural resources to previously unnacessible tropical regions (Peres 2010). Due to these pressures, an increasing proportion of protected areas has allowed some kind of resource exploitation, usually under a defined set of conditions. Thus, many exploited species now depend on sustainability for their survival across large areas. Besides, because of the complex networks of ecological interactions, exploitation of a natural resource can also affect populations of other species through cascading effects (Peres 2010). Therefore, sustainable use of natural resources is an important conservation question.

Herein we reviewed studies which analysed the sustainability of the use of three types of natural resources - timber, non-timber forest products (NTFP) and hunting - in Brazil.

\footnotetext{
*Send correspondence to: Fernando Antonio dos Santos Fernandez

Departamento de Ecologia, Universidade Federal do Rio de Janeiro - UFRJ, CP 68020 ,

CEP 21941-590, Rio de Janeiro, RJ, Brazil

e-mail: rodentia@biologia.ufrj.br
}

Besides, we also reviewed studies on the cascading effects linked to these exploitations. These resource categories correspond to those used in Peres' (2010) review on overexploitation, with the exception of aquatic resources.

Whenever a "natural resource" is an exploited animal or plant, it is also a biological population. Thus "sustainable use" can be translated as use which allows a population to survive, implying that losses (by mortality, due to exploitation or not, and by emigration) are balanced on the long run by gains (by natality and immigration). Therefore, a demographic approach is a precondition for evaluating if the exploitation is sustainable or not (Sutherland 2001). Following directly from Brundtland's definition, we used as the criterion of sustainability that the exploitation regime would allow the resource to keep on existing for future generations, in order to provide for their needs - which in general tend to increase or at least to remain constant.

\section{Methods}

We analysed studies which appeared in articles or in theses, from 1987 to June 2010, using the following keywords (in English and also in Portuguese for theses): conventional logging, forest management, game management, harvest, hunting, logging, non-timber forest products, NTFP, poaching, reduced impact logging, RIL, selective logging, sustainability, sustainable, timber. Articles were searched in Web of Science and theses (on agronomy, anthropology, botany, ecology, forest resources, forest engineering, general 
biology and zoology) in the sites Domínio Público (2010) and Banco de Teses (CAPES 2010).

Some studies involved more than one taxonomic group (e.g., studies on hunting investigating several game species). Thus we use "case" to refer to each taxonomic group evaluated in one study. Taxonomic groups were usually species, although sometimes larger groups such as "primates" or "ungulates"were used. In some studies, exploitation of a species was analysed in more than one locality. However, this counted as a single case, as our definition of cases was based on a taxonomic (rather than geographic) criterion. Our definition prevented comparisons being disproportionately influenced by the few studies with many localities.

For each study, we first asked if sustainability was actually tested or not. As sustainability is essentially a demographic question, we selected the studies with a demographic approach, that is, those which presented demographic information - which could consist of estimates of population density, relative abundance, age or size structure, or tree basal areas or recovery rates.

Quantitative analyses on sustainability were run only for studies with a demographic approach, by asking the question: was the use of resources sustainable or not? As the criterion for answering this question, we used the authors' conclusion of each study, regarding the maintenance or not of resource levels. In a few cases, when this was not explicity stated, we used the conclusion implicit in the results. The analysis was carried out in a case-by-case basis, as different species in the same study could be exploited in sustainable or non-sustainable ways. Thus different cases within a study should not represent pseudoreplication (Hurlbert 1984).

Besides sustainability of the resource itself, we also analysed studies on cascading effects on other species affected indirectly by the exploitation, by comparing proportions of cases where the exploitation process decreased or not the abundance of non-resource species.

We also compared the outcomes of analyses with three kinds of demographic approaches. First, studies based on spatial variation of abundance, that is, comparing sites where the resource was exploited with sites where it was not. Second, studies based on temporal variation of abundance, that is, comparing levels before and after the exploitation started. Third, studies which performed demographic analyses, either by following the abundance of the exploited population along time, or by using measured parameters to forecast population trends, as in forestry studies using age structures and simulations to project future changes.

Caution is needed when analysing sustainability of hunting through spatial variation of abundance. A basic principle of management is that a exploited population is usually kept below its carrying capacity, because productivity is maximized at intermediate densities (Sutherland 2001). Thus, reduced population levels, by themselves, not necessarily imply unsustainable exploitations. To address this problem, we followed Robinson \& Redford's (1991), who proposed that for large mammal populations sustainable yield is often around $60 \%$ of carrying capacity. With the additional assumption that populations in the non-hunted areas were near their carrying capacities, we only considered unsustainable cases where density fell $>60 \%$ in hunted as compared to non-hunted areas.

We compared frequencies of sustainable and unsustainable cases among categories of resource type and demographic approach, using G-tests (Zar 1999) with Williams' correction.

\section{Results}

We found 64 studies on exploitation of natural resources in Brazil (see Additional Supporting Information at www. abeco.org). These studies included a total of 239 cases, 133 of which (55.6\%) referred to sustainability of the resource itself, and 106 (44.4\%) to cascading effects. Hunting studies mostly concerned mammals or ground-dwelling game birds; three cases referred to reptiles. All studies reagarding timber were either on reduced impact logging (RIL) or selective logging. Most studies (81.3\%) were carried out in the Amazonian Forest biome (Table 1), with some in Atlantic Forest, Pantanal, Cerrado and Caatinga. Only 47 studies (73.4\%) had a demographic approach; these comprised 192 cases, $126(65.6 \%)$ referring to sustainability itself and 66 $(34.4 \%)$ to cascading effects.

When dealing with sustainability itself, with all resources pooled, we found 65 cases of sustainable exploitations, and 61 cases of unsustainable ones. The proportions of sustainable and unsustainable cases were similar $\left(\mathrm{G}_{\text {Williams }}=0.0631, \mathrm{df}=1, \mathrm{p}=0.8016\right)$. Unsustainable exploitations were most common in timber (24/39 cases), intermediate for hunting (35/78) and least common for NTFP (2/9) (Table 2). However, proportion of sustainable cases did not differ significantly among resource types $\left(G_{\text {Williams }}=5.536, d f=2, p=0.0628\right)$.

For each type of resource, different demographic approaches yielded different conclusions concerning the proportion of sustainable cases. Hunting cases studied through demographic analysis were regarded as sustainable more often, while a higher proportion of those cases approached through spatial comparation of abundances were unsustainable (Table 2, $\mathrm{G}_{\text {Williams }}=6.7453, \mathrm{df}=1, \mathrm{p}<0.0094$ ). Timber cases revealed the opposite pattern (Table 2, $\mathrm{G}_{\text {Williams }}=19.666, \mathrm{df}=2, \mathrm{p}<0.0001$ ).

Not detecting cascading effects was more common than detecting them (Table 3, $\chi_{\text {Yates }}^{2}=28.015, \mathrm{df}=1$, $\mathrm{p}<0.0001)$. The three categories of resources had similar proportions of cases implying damage and not (Table 3, $\mathrm{G}_{\text {Williams }}=0.3566, \mathrm{df}=2, \mathrm{p}=0.8367$ ). 
Table 1. Numbers of studies $(n=64)$ and of cases $(n=239)$ dealing with natural resource exploitations on Brazil, according with type of resource and biome. Each study is a given article or thesis (references in Appendix S1). Each case refers to a taxonomic group (usuallly a species) investigated in one study.

\begin{tabular}{lccc}
\hline & Number of studies & Number of cases & Study \# (in Appendix S1) \\
\hline Resource exploitation & 10 & 94 & $1-10$ \\
Hunting & 12 & 44 & $11-22$ \\
NTFP* & 42 & 101 & $23-64$ \\
Timber & & & \\
Biome & 52 & 195 & $2,4-10,12-16,18,22-29,33-51,53-63$ \\
Amazonian Forest & 6 & 27 & $1,11,17,30,31,52$ \\
Atlantic Forest & 4 & 15 & $19,20,32,64$ \\
Cerrado & 1 & 1 & 3 \\
Pantanal & 1 & 1 & 21 \\
Caatinga & &
\end{tabular}

${ }^{*}$ Non-timber forest products.

Table 2. Number of cases that evaluated the sustainability for each resource exploited, type of demographic approach $(n=126)$, and final conclusion (sustainable or unsustainable).

\begin{tabular}{|c|c|c|c|c|}
\hline & $\begin{array}{c}\text { Temporal variation of } \\
\text { abundance }\end{array}$ & $\begin{array}{c}\text { Spatial variation of } \\
\text { abundance }\end{array}$ & $\begin{array}{l}\text { Demographic } \\
\text { analysis }\end{array}$ & Total \\
\hline \multicolumn{5}{|l|}{ Hunting } \\
\hline Sustainable & 0 & 12 & 31 & 43 \\
\hline Unsustainable & 0 & 20 & 15 & 35 \\
\hline Total & 0 & 32 & 46 & 78 \\
\hline \multicolumn{5}{|l|}{ NTFP* $^{*}$} \\
\hline Sustainable & 3 & 3 & 1 & 7 \\
\hline Unsustainable & 1 & 0 & 1 & 2 \\
\hline Total & 4 & 3 & 2 & 9 \\
\hline \multicolumn{5}{|l|}{ Timber } \\
\hline Sustainable & 1 & 13 & 1 & 15 \\
\hline Unsustainable & 0 & 4 & 20 & 24 \\
\hline Total & 1 & 17 & 21 & 39 \\
\hline
\end{tabular}

${ }^{\star}$ Non-timber forest products.

Table 3. Number of cases that evaluated the cascading effects of each resource exploitation, type of demographic approach ( $\mathrm{n}=66$ ), and final conclusion (cascading effects detected or not detected).

\begin{tabular}{lcccc}
\hline & $\begin{array}{c}\text { Temporal variation of } \\
\text { abundance }\end{array}$ & $\begin{array}{c}\text { Spatial variation of } \\
\text { abundance }\end{array}$ & $\begin{array}{c}\text { Demographic } \\
\text { analysis }\end{array}$ & Total \\
\hline Hunting & 0 & 14 & 0 & 14 \\
$\quad$ Not detected & 0 & 2 & 0 & 2 \\
$\quad$ Detected & 0 & 16 & 0 & 16 \\
$\quad$ Total & 0 & 16 & 0 & 16 \\
NTFP* & 0 & 3 & 0 & 3 \\
$\quad$ Not detected & 0 & 19 & 0 & 19 \\
Detected & & & & \\
Total & 6 & 19 & 0 & 25 \\
Timber & 0 & 6 & 0 & 6 \\
$\quad$ Not detected & 6 & 25 & 0 & 31 \\
Detected & & & & \\
Total & & & & \\
\hline
\end{tabular}

${ }^{*}$ Non-timber forest products. 


\section{Discussion}

Overall, about half of the exploitations of natural resources studied were unsustainable. This finding is important by itself, as it shows the need for improving the management of natural resources in Brazil if we wish to follow Brundtland's laudable goal of keeping them for future generations.

For hunting, nearly half of the exploitations were found to be unsustainable. Shifts in hunted species detected in some studies (Peres \& Dolman 2000; Jerozolimski \& Peres 2003) reinforce the conclusion that unsustainable hunting is common in Brazil. The preferred species are usually mammals and birds with low reproductive rates and population densities. Even if a population manages to survive at low densities, it may be too scarce to fulfill its ecological roles within the community, that is, it may be ecologically extinct (Redford 1992). Indeed, abundances were often severely reduced, by about $60-90 \%$ or more (Cullen Junior et al. 2000; Peres \& Dolman 2000; Peres \& Palacios 2007), especially for species such as tapirs, white-lipped peccaries and howler monkeys which are particularly vulnerable (Peres 2001; Parry et al. 2009).

For timber, the proportion of unsustainable cases may be overestimated in studies based on spatial variation of abundances, for the same reason as for hunting (lowered densities not necessarily mean unsustainable exploitations). However, timber was more often studied through demographic analysis. It is easier to obtain detailed information - e.g. age structures - for trees than for animal populations; besides, such studies are routinely used in forestry for predicting future harvests. The results of demographic analyses for timber were alarming: harvest levels are expected to fall in 20/21 cases, even with RIL (Sist \& Ferreira 2007; Schulze et al. 2008a, b). These findings show that the 30 year rotation, defined by Brazilian law for Amazonia, is too short. Minimum rotation time should be defined case by case, according to the species composition of each stand and soil features, on the basis of demographic analyses.

The scarctiy of studies on the sustainability of the exploitation of NTFP in Brazil is troubling. The few studies available found it sustainable more often than the other resources. However, most studies, based on temporal comparisons of abundance, were too short for detecting long-term trends. Besides, one of the two unsustainable cases - revealed by the most sophisticated method, demographic analysis - is the exploitation of the Brazilian Nut, probably the most important NTFP in Brazil (Peres et al. 2003). The high proportion of sustainable cases in our analysis can be misleading, and the sustainability of NTFP exploitation in Brazil needs more testing, given its socioeconomic importance.

Regarding cascading effects, one can hardly imagine that any natural resource can be exploited within an ecosystem without colateral effects. Yet most studies have not detected negative effects of resource exploitation on other species. This can actually mean that cascading effects of resource exploitations were rare. Nevertheless, some studies may have failed to find cascading effects because they evaluated species not likely to be affected anyway; e.g. Cullen Junior $e t$ al. (2000) reported lack of cascading effects of hunting on populations of non-hunted species - but there is no reason to expect that they should decrease with the removal of game. In a few cases, however, important cascading effects were detected, e.g., RIL can affect forest structure making the habitat unsuitable for bats (Castro-Arellano et al. 2007, 2009), birds (Barlow et al. 2006) and fish (Dias et al. 2009). Cascading effects caused even by a particularly careful technique such as RIL is a disturbing result. The main question about cascading effects does not seem to be if they exist or not, but rather where to search for them and if their magnitude is tolerable or not. Clearly cascading effects must also be taken in account when assessing the sustainability of resource exploitations.

The high proportion of unsustainable cases we found raises deep concern, because they represent mostly situations where sustainability would be expected. For example, all cases of timber exploitation studied referred either to RIL or to selective logging, techniques often regarded as sustainable (Castro-Arellano et al. 2007; Costa \& Magnusson, 2003). Similarly, most studies on NTFP referred to exploitations in indigenous land or Extrativist Reserves (e.g. Plowden et al. 2003; Wadt et al. 2008). Resource management in these areas is supposedly sustainable by definition of these categories of reserves (Brasil 2006). In the case of hunting, most studies analysed referred to subsistence hunting in Amazonia by local peoples (e.g. Peres 1996; Peres \& Dolman 2000). The implications of this point are far-reaching. First, several expressions like "sustainable use", "sustainable exploitation" and so on, in Brazilian environmental law and even in the name of reserve categories (e.g. "Sustainable Development Reserve"), are unsupported or misleading in many cases, and should be reviewed. Second, we should use "sustainability" more carefully. It would be highly desirable that any claimed "sustainable use" of timber, hunting or NTFP should be tested for its actual sustainability, using a demographic approach. New concessions for exploitation in public land or reserves, as well as renewing existing concessions, should be conditioned to the exploitation being demonstrably sustainable.

In a more general outlook, our results invite a reflection on the misuses of the sustainability concept (Inyang et al. 2009). One reason for the popularity of the word "sustainable" is surely because it says exactly what everybody wants to hear - that something conciliates development with conservation. However, it is so popular also because it sounds as being based on knowledge. When a given exploitation is labeled as "sustainable", we tend to infer that somebody must have studied it and demonstrated it. Thus, using the concept of sustainability too loosely is quite dangerous. A given practice of resource use may well cause less impact 
than alternative ones, and yet be unsustainable. If any inference of sustainability is unwarranted, the implications for conservation and social issues are manifold. False sustainability is not good for anyboby - neither for the biological species we call resource, nor for people estimulated to depend on it. Sustainability is an immense and influential idea we need to use carefully, guided by scientific information rather than by wishful thinking.

\section{Acknowledgements}

Fundação O Boticário de Proteção à Natureza provided financial support. M. Milano first supported this idea, and Grupo do Iguaçú supported it thereafter. We thank A. Pires, M. Galliez and R. Parentoni for their comments.

\section{References}

Barlow J et al., 2006. The responses of understorey birds to forest fragmentation, logging and wildfires: an Amazonian synthesis. Biological Conservation, 128:182-192. http:// dx.doi.org/10.1016/j.biocon.2005.09.028

Brasil. Ministério do Meio Ambiente. Sistema Nacional de Unidades de Conservação da Natureza - SNUC, 2006. Decreto $\mathrm{n}^{\circ} 4.340$, de 22 de agosto de 2002. Regulamenta artigos da Lei n 9.985, de 18 de julho de 2000, que dispõe sobre o Sistema Nacional de Unidades de Conservação da Natureza - SNUC, e dá outras providências. Diário Oficial da República Federativa do Brasil, Brasília (2002 ago. 23).

Castro-Arellano I et al., 2007. Effects of reduced impact logging on bat biodiversity in terra firme forest of lowland Amazonia. Biological Conservation, 138:269-285. http:// dx.doi.org/10.1016/j.biocon.2007.04.025

Castro-Arellano I et al., 2009. Reduced-impact logging and temporal activity of understorey bats in lowland Amazonia. Biological Conservation, 142:2131-2139. http://dx.doi. org/10.1016/j.biocon.2009.04.013

Coordenação de Aperfeiçoamento de Pessoal de Nível Superior - CAPES. Banco de Teses, 2010. Brasília. Available from: <http://capesdw.capes.gov.br/capesdw>. Access in: june 2010.

Costa FRC \& Magnusson WE, 2003. Effects of selective logging on the diversity and abundance of flowering and fruiting understory plants in a central Amazonian Forest. Biotropica, 35:103-114.

Cullen Junior L et al., 2000. Effects of hunting in habitat fragments of the Atlantic forests, Brazil. Biological Conservation, 95:4956. http://dx.doi.org/10.1016/S0006-3207(00)00011-2

Dias MS et al., 2009. Effects of reduced-impact logging on fish assemblages in central Amazonia. Conservation Biology, 24:278-286. PMid:19681987. http://dx.doi. org/10.1111/j.1523-1739.2009.01299.x

Domínio Público, 2010. Brasília. Available from: <http://www. dominiopublico.gov.br/pesquisa/PesquisaPeriodico Form. jsp>. Access in: june 2010.

Hurlbert SH, 1984. Pseudoreplication and the design of ecological field experiments. Ecological Monographs, 54:187-211. http://dx.doi.org/10.2307/1942661
Inyang HI et al., 2009. Sustaining sustainability: approaches and contexts. Journal of Environmental Management, 90:36873689. PMid:19497658. http://dx.doi.org/10.1016/j. jenvman.2008.05.024

Jerozolimski A \& Peres CA, 2003. Bringing home the biggest bacon: a cross-site analysis of the structure of hunter-kill profiles in Neotropical forests. Biological Conservation, 111:415-425. http://dx.doi.org/10.1016/ S0006-3207(02)00310-5

Parry L et al., 2009. Hunting for sustainability in tropical secondary forests. Conservation Biology, 23:1270-1280. PMid:19765039. http://dx.doi.org/10.1111/j.1523-1739.2009.01224.x

Peres CA, 1996. Population status of white-lipped Tayassu pecari and collared peccaries T. tajacu in hunted and unhunted Amazonian Forest. Biological Conservation, 77:115-123. http://dx.doi.org/10.1016/0006-3207(96)00010-9

Peres CA, 2001. Synergistic effects of subsistence hunting and habitat fragmentation on Amazonian forest vertebrates. Conservation Biology, 15:1490-1505. http://dx.doi. org/10.1046/j.1523-1739.2001.01089.x

Peres CA, 2010. Overexploitation. In: Sodhi NJ. \& Ehrlich PR (eds.). Conservation biology for all. Oxford: Oxford University Press. p. 107-130. http://dx.doi.org/10.1093/ acprof:oso/9780199554232.003.0007

Peres CA \& Dolman PM, 2000. Density compensation in neotropical primate communities: evidence from 56 hunted and nonhunted Amazonian forests of varying productivity. Oecologia, 122:175-189. http://dx.doi.org/10.1007/ PL00008845

Peres CA \& Palacios E, 2007. Basin-wide effects of game harvest on vertebrate population densities in Amazonian. Biotropica, 39:304-315. http://dx.doi. org/10.1111/j.1744-7429.2007.00272.x

Peres CA et al., 2003. Demographic threats to the sustainability of Brazil nut exploitation. Science, 302:2112-2114. PMid:14684819. http://dx.doi.org/10.1126/science.1091698

Plowden C. et al., 2003. The ecology and harvest potential of titica vine roots (Heteropsis flexuosa: Araceae) in the eastern Brazilian Amazon. Forest Ecology and Management, 182:59-73. http://dx.doi.org/10.1016/ S0378-1127(03)00030-6

Redford KH, 1992. The empty forest. BioScience, 42:412-422. http://dx.doi.org/10.2307/1311860

Robinson J \& Redford KH, 1991. Neotropical wildlife use and conservation. Chicago: University of Chicago Press.

Schulze M et al., 2008a. How rare is too rare to harvest? Management challenges posed by timber species occurring at low densities in the Brazilian Amazon. Forest Ecology and Management, 256:1443-1457. http://dx.doi.org/10.1016/j. foreco.2008.02.051

Schulze M et al., 2008b. Evaluating ipê (Tabebuia, Bignoniaceae) logging in Amazonia: sustainable management or catalystic for forest degradation? Biological Conservation, 141:2071-2085. http://dx.doi.org/10.1016/j.biocon.2008.06.003

Sist P \& Ferreira FN, 2007. Sustainability of reduced-impact logging in the Eastern Amazon. Forest Ecology and 
Management, 243:199-209. http://dx.doi.org/10.1016/j. foreco.2007.02.014

Sutherland WJ, 2001. Sustainable exploitation: a review of principles and methods. Wildlife Biology, 7:131-140.

Wadt LHO et al., 2008. Sustainable forest use in Brazilian extractive reserves: natural regeneration of Brazil nut in exploited populations. Biological Conservation, 141:332-346. http://dx.doi.org/10.1016/j.biocon.2007.10.007

World Commission on Environment and Development. 1987. Brundtland Report: Our Common Future. New York: Oxford University Press.

Zar JH, 1999. Biostatistical analysis. New Jersey: Prentice Hall.

Received: December 2011

First Decision: March 2012

Accepted: April 2012 